\title{
ОРГАНІЗАЦЙНА ПІДТРИМКА ТА ІНФОРМАЦЙНО-ПРОСВІТНИЦЬКЕ СПРИЯННЯ МІСЦЕВИХ ДЕРЖАВНИХ АДМІНІСТРАЦІЙ ПРОЦЕСУ ДОБРОВІЛЬНОГО ОБ'ЄДНАННЯ ТА ПРИЄДНАННЯ ТЕРИТОРІАЛЬНИХ ГРОМАД
}

\begin{abstract}
Анотація. У статті проаналізовано правові підстави та законодавче регулювання відносин місцевих державних адміністрацій з органами місцевого самоврядування, що представляли відповідні територіальні громади у процесі добровільного об’еднання територіальних громад. Наведено та здійснено аналіз нормативної бази, що регулюе процеси добровільного об’еднання територіальних громад у тій частині, де відбувалася взаємодія місцевих державних адміністрацій та органів місцевого самоврядування, що представляли відповідні територіальні громади у процесі добровільного об’еднання територіальних громад. У межах даного наукового дослідження сформульовано поняття добровільного об’еднання територіальних громад, вказано на переваги та недоліки обов'язку місцевих державних адміністрацій здійснювати організаційну підтримку та інформаційно-просвітницьке сприяння територіальних громад у процесі добровільного об’єднання територіальних громад як з боку позитивного впливу на швидкість та повноту отримання консультацій органами місцевого самоврядування, так і вказано на існування корупційних ризиків.
\end{abstract}

Ключові слова: добровільне об'єднання територіальних громад, місцеві державні адміністрації, приєднання територіальних громад, місцеве самоврядування, децентралізація.

Petrushevska Valentyna

Dnipropetrovsk State University of Internal Affairs

\section{ORGANIZATIONAL SUPPORT, INFORMATION AND EDUCATIONAL ASSISTANCE OF LOCAL STATE ADMINISTRATIONS IN THE PROCESS OF VOLUNTARY ASSOCIATION AND ACCESSION OF TERRITORIAL COMMUNITIES}

Summary. This paper analyzes the legal basis and legislative regulation of relations between local state administrations and local governments representing the relevant territorial communities in the process of voluntary association of territorial communities. The article presents and analyzes the regulatory framework governing the processes of voluntary association of territorial communities in the part where the interaction of local state administrations and local governments, represented the respective territorial communities in the process of voluntary association of territorial communities. Also, on the basis of a special law, the concept of voluntary association of territorial communities as based on the foundations of constitutionality and legality, voluntariness, economic efficiency, state support, ubiquity of local self-government, transparency and openness, responsibility of the process of consolidation of administrative-territorial units territorial communities within one oblast, taking into account historical, natural, ethnic, cultural and other factors influencing the socio-economic development of the united territorial community, initiated by community members directly or indirectly through representatives of elected local governments. This research also highlights the advantages and disadvantages of the obligation of local state administrations to provide organizational support and informational and educational assistance to local communities in the process of voluntary association of local communities in terms of positive impact on the speed and completeness of local government consultations. and indicated the existence of corruption risks. Thus, despite some regulatory irregularities in the voluntary unification of territorial communities, we can talk about the ability of the local government of Ukraine to interact effectively with state institutions, the ability to counteract decisions or illegal actions of state institutions under current legislation, despite some unwillingness of state institutions to abstain. from actions that limit local self-government bodies as the foundations of a democratic regime and meet the challenges of a democratic society on the example of interaction with local state administrations in the process of voluntary unification of territorial communities.

Keywords: voluntary association of territorial communities, local state administrations, accession of territorial communities, local self-government, decentralization.

$\Pi$ остановка проблеми. Протягом перший етап редори децентрарізай тривав елементів якого передбачалося створення спроможних територіальних громад шляхом укрупнення існуючих територіальних громад. Після завершення процесу добровільного об'єднання територіальних громад, органам місцевого самоврядування таких громад передавалися повноваження, ресурси та відповідальність від органів виконавчої влади. Оскільки ключовим критерієм як усієї реформи децентралізації, так і у питанні формування кожної окремої об'єднаної територіальної громади була категорія "спроможність" (як виконувати повноваження, управляти ресурсами так і нести відповідальність за наслідки прийняття таких владних рішень), то передбачалося, що громадяни, котрі проживали у громадах, будуть зацікавлені у такому процесі.

$\mathrm{У}$ той же час, за даними Моніторингу процесу децентралізації та реформування місцевого самоврядування Міністерства розвитку громад та територій України станом на 10 січня 2020 року в Україні було створено 1029 об'єднаних територіальних громад (4698 громад до об'єднання) 
3 населенням 11,7 мільйонів людей. Проте 6263 громад на момент презентації результатів Моніторингу ще не об'єдналися [1, с. 7].

Аналізуючи проблеми, що постали перед територіальними громадами на місцевому рівні на шляху до об'еднання, можна виділити такі чинники, як недостатня поінформованість та, відповідно, зацікавленість жителів громад, маніпулювання громадською думкою - тобто інфрормаційні, корупційні чи політичні аспекти. У той же час громади, які свідомо прагнули до об'єднання, стикалися, з вимогами безпомилкового правозастосування нормативної бази, покликаної регулювати власне процес добровільного об'єднання. Таким чином, перед державою постала проблема протидії даній рефрормі як через суб'єктивні, так i через об’єкивні чинники. Тому виникла нагальна потреба моніторингу, аналізу та надання методичної допомоги територіальним громадам на шляху до об’єднання.

Частиною другою статті 9 Закону України "Про добровільне об'єднання територіальних громад" передбачено, що організащійну підтримку та інформаційно-просвітницьке сприяння добровільному об'еднанню територіальних громад та приєднанню до об'єднаних територіальних громад забезпечують Рада міністрів Автономної Республіки Крим, місцеві державні адміністрації [2].

Дослідження питання правового регулювання взаємодії місцевих державних адміністрацій та органів місцевого самоврядування, що представляють відповідні територіальні громади на прикладі процесу добровільного об'єднання територіальних громад дозволить проаналізувати як спроможність системи місцевого самоврядування України едективно взаємодіяти 3 державними інституціями, здатність як протидіяти рішенням чи неправомірним діям державних інституцій у рамках чинного законодавства, так і готовність державних інституцій належним чином гарантувати незалежність дій та рішень місцевого самоврядування як підвалини демократичного режиму.

Аналіз останніх досліджень і публікацій. Дослідженню процесів, окремих аспектів та оцінки результатів добровільного об'єднання територіальних громад присвятили свої роботи такі вчені як Західна О. Р., Гайдар М. Є., Миклащук I., Бельська Т. В., Сергієнко А. А., Журавель Я., Назиров К. З. Проте питання практичних аспектів взаємодії саме місцевих державних адміністрації із органами місцевого самоврядування, що представляють відповідні територіальні громади ще потребуе окремих досліджень.

З приводу невирішених раніше частин загальної проблеми, яким присвячуеться стаття, слід зазначити наступне. Районні та обласні державні адміністрації брали безпосередню участь в процесі укрупнення територіальних громад, як необхідного елементу реформи децентралізації, шляхом визначеної законодавством інформаційної підтримки, а також через схвалення проектів рішень про добровільне об'єднання територіальних громад, без якого не могли бути призначені перші вибори у новооб'єднаних територіальних громадах. У той же час в процесі такого укрупнення були відсутні наукові дослідження, присвячені ролі цих органів в процесі добровільного об'єднання територіальних громад, що на практиці мало негативні наслідки як через перевищення повноважень місцевими державними адміністраціями, так і через самоусунення останніх від інформаційно-організаційної підтримки територіальних громад.

Завданнями цієї статті $є$ визначення поняття добровільного об'єднання та приеднання територіальних громад, дослідження аспектів методичного керівництва місцевих державних адміністрацій процесом добровільного об'еднання та приєднання територіальних громад.

Метою статті вбачається встановлення спроможності органів місцевого самоврядування України відповідати викликам демократичного суспільства на прикладі взаємодії 3 місцевими державними адміністраціями у процесі добровільного об'єднання територіальних громад.

Виклад основного матеріалу дослідження. Ідею добровільного об'єднання територіальних громад було закріплено у статті 140 Конститущії України [3] та статті 6 Закону України "Про місцеві державні адміністраці1" [4] ще з 1996 та 1997 років відповідно. Проте суперечливість положень цих норм, зокрема, надання права на об'єднання виключно сільським територіальним громадам, вимоги проведення місцевих редерендумів без закріплення на законодавчому рівні прозорих та чітких вимог до таких процедур не надали реальної можливості для правозастосування цих норм. Тому, враховуючи особливості державного устрою та належність українського законодавства до романо-германської правової сім'ї, неврегульованість процедури об'єднання навіть сільських територіальних громад, перетворювало дані норми на суто декларативні. Крім того, необхідно зважати не лише на практичну, але і на політичну проблематику прийняття такого рішення без належної процедури - навіть у разі успішного редерендуму, закономірно, залишились би члени територіальної громади, що не схвалювали такого рішення. Такі особи, як і кожен, мали і мають конституційні права на оскарження дій та рішень органів місцевого самоврядування чи органів державної влади, що взяли на себе відповідальність за організацію такого рішення, у тому числі шляхом звернення до правоохоронних та судових органів, що могло б мати негативні наслідки не лише для відповідальних за процеси об'єднання територіальних громад осіб, але і понесло б бюджетні та репутаційні втрати для громад в цілому.

Ситуація змінюеться після перемоги Револющії гідності - 01.04.2014 Розпорядженням Кабінету Міністрів України № 333-р схвалено Концепцію редормування місцевого самоврядування та територіальної організації влади в Україні. Даним документом визначено проблеми, які потребували розв'язання; мету Концепції; шляхи і способи розв'язання проблем; принципи редормування місцевого самоврядування та територіальної організації влади; завдання редрорм: "Забезпечення доступності та якості публічних послуг”, “Досягнення оптимального розподілу повноважень між органами місцевого самоврядування та органами виконавчої влади”, "Визначення обгрунтованої територіальної основи для діяльності органів місцевого само- 
врядування та органів виконавчої влади з метою забезпечення доступності та належної якості публічних послуг, що надаються такими органами”, “Створення належних матеріальних, фрінансових та організаційних умов для забезпечення виконання органами місцевого самоврядування власних і делегованих повноважень"; етапи реалізації Концепції; очікувані результати, а також обсяг фрінансових ресурсів.

На виконання даної Концепції 18.06.2014 розпорядженням Кабінету Міністрів України № 591-р було затверджено План заходів щодо реалізації Концепції рефрормування місцевого самоврядування та територіальної організації влади в Україні, яким визначено строки та заходи, спрямовані на реалізацію редорми децентралізації. Проте 22.09.2016 розпорядженням Кабінету Міністрів України № 688-р “Деякі питання реалізації Концепції реформування місцевого самоврядування та територіальної організації влади в Україні” затверджено новий План заходів щодо реалізації Концепції редормування місцевого самоврядування та територіальної організації влади в Україні.

$\mathrm{У}$ результаті розроблено та прийнято спеціальний закон першого етапу реформи децентралізації - Закон України "Про добровільне об'єднання територіальних громад”, який не лише належним чином визначив процедуру, права та обов'язки учасників процесу добровільного об'єднання територіальних громад, але i розширив перелік громад, яким надано право на добровільне об'єднання, включивши до даного процесу селищні та міські територіальні громади. Крім того, Законом України "Про внесення змін до деяких законів України щодо добровільного приєднання територіальних громад” від 09.02.2017 № 1851-VIII [6] запроваджено інститут приєднання територіальних громад до об’єднаних територіальних громад, що визначило механізми нарощування території об'єднаної територіальної громади до меж, які відповідають Перспективному плану спроможної територіальної громади, шляхом приєднання територіальних громад. При цьому правовідносини врегульовано таким чином, що перехід у нову якість для об'єднаної територіальної громади відбуваеться після досягнення нею параметрів, які свідчать про їі фрактичну спроможність, та є політично виправданим [7].

Таким чином, дослідивши місце процесу добровільного об'єднання територіальних громад у першому етапі редорми децентралізації, можливо, на основі вищенаведених нормативноправових актів сформулювати теоретичне поняття такого правового явища як “добровільне об'єднання територіальних громад”.

Добровільне об'єднання територіальних громад - це заснований на підвалинах конституційності та законності, добровільності, економічної ефрективності, державної підтримки, повсюдності місцевого самоврядування, прозорості та відкритості, відповідальності процес укрупнення адміністративно-територіальних одиниць шляхом об'єднання суміжних територіальних громад у межах однієї області з урахуванням історичних, природних, етнічних, культурних та інших чинників, що впливають на соціально-економіч- ний розвиток об'єднаної територіальної громади, ініціаторами якої виступають члени громади прямо або опосередковано через представників виборних органів місцевого самоврядування.

Статтею 9 Закону України "Про добровільне об'єднання територіальних громад" визначено, що держава здійснюе інформаційно-просвітницьку, організаційну, методичну та фінансову підтримку добровільного об'єднання територіальних громад та приєднання до об'єднаних територіальних громад. Організаційну підтримку та інфрормаційно-просвітницьке сприяння добровільному об,єднанню територіальних громад та приєднанню до об'єднаних територіальних громад забезпечують Рада міністрів Автономної Республіки Крим, місцеві державні адміністрації [2].

Так, законом України "Про місцеві державні адміністращї” визначено, що виконавчу владу в областях і районах, містах Киеві та Севастополі здійснюють місцеві державні адміністращії. Місцева державна адміністрація є місцевим органом виконавчої влади і входить до системи органів виконавчої влади [8].

Правовими підставами участі місцевих державних адміністрацій, окрім визначених Законом України “Про добровільне об'єднання територіальних громад" положень е також норми спеціального закону. А саме визначена Законом України "Про місцеві державні адміністрації" компетенція місцевих державних адміністрацій в межах відповідної адміністративно-територіальної одиниці забезпечувати виконання Конституції, законів України, актів Президента України, Кабінету Міністрів України, інших органів виконавчої влади вищого рівня; здійснювати взаємодію з органами місцевого самоврядування; а також реалізацію інших наданих державою, а також делегованих відповідними радами повноважень [8].

У той же час форми такої організаційної підтримки та інформаційно-просвітницького сприяння окремим нормативним документом не визначені. Окремі положення щодо способів виконання цього завдання держави були доведені до облдержадміністрацій окремими дорученнями Кабінету Міністрів чи Міністерства регіонального розвитку України (Міністерства розвитку громад та територій України). Так, зокрема, шляхом поширення методичних, інформаційно-просвітницьких матеріалів, розроблених як спеціалістами Мінекономрозвитку так i міжнародними організаціями: швейцарсько-українського проекту «Підтримка децентралізації в Україні» (DESPRO), Програма «Децентралізація приносить кращі результати та едективність» (DOBRE), тощо. Крім методичних рекомендащій ці та ряд інших міжнародних організацій також надали Україні фінансову допомогу на проведення реформ децентралізації [9].

Проте роль місцевих державних адміністрацій, як об'єднаних в систему відповідальних за організаційну підтримку та інформаційно-просвітницьке сприяння органів державної влади полягає не лише у поширенні тієї чи іншої просвітницької індрормації, яка створена третіми особами, але i надання власних консультащій та допомоги (у рамках чинного законодавства) у кожному конкретному випадку, з яким може 
стикнутися та чи інша територіальна громада на шляху до об'єднання чи приєднання. Перевага взаємодії органів місцевого самоврядування у питаннях, пов'язаних 3 організаційними чи інформаційними проблемами полягає саме у законодавчо закріпленому обов'язку цих органів державної влади надавати консультації, роз'яснення та рекомендації у межах чинного законодавства органам місцевого самоврядування. У той же час принцип незалежності місцевого самоврядування при цьому не порушується, оскільки прийняття рішення щодо способу дії, урахування чи неврахування таких консультацій лежить виключно на суб'єктах місцевого самоврядування, відповідальних за процеси добровільного об'єднання територіальних громад.

$\mathrm{У}$ той же час при такій організації роботи постає проблема можливості маніпулювання інформаціею з боку посадових осіб місцевих державних адміністрацій, відповідальних за інформаційнопросвітницьке сприяння. Особливо на рівні районних державних адміністрацій - оскільки після завершення перших виборів спроможних об'єднаних територіальних громад до бюджету останніх зараховуються ті види податків, які до џого, згідно Бюджетного кодексу, зараховувалися до районного бюджету, розпорядником окремих заходів якого були, у тому числі, структурні підрозділи районних державних адміністрацій. Відповідно, виникає необхідність перерозподілу коштів, якими фрінансуються бюджетні програми районного рівня, у чому часто окремі працівники районних державних адміністрацій були не зацікавлені.

Так, до бюджетів об'єднаних територіальних громад, крім доходів, що отримували бюджети до їх об'єднання, зараховується 60\% податку на доходи фізичних осіб. Раніше цей податок зараховувався до районного бюджету. Перелік доходних джерел бюджетів об'єднаних територіальних громад визначено статтями 64 (загальний фронд), 69-1 (спеціальний фонд) та 71 (бюджет розвитку) Бюджетного Кодексу [10].

У той же час, такі корупщійні ризики можливо частково нівелювати при консультуванні органів місцевого самоврядування про процес добровіль- ного об'єднання територіальних громад не районними, а обласними державними адміністраціями.

Таким чином, закріплення законодавцем за місцевими державними адміністраціями обов'язку організаційної підтримки та інформаційно-просвітницького сприяння територіальних громад у процесі добровільного об'єднання територіальних громад позитивно вплинуло на швидкість та повноту отримання консультацій органами місцевого самоврядування, хоча i не виключило корупщійних ризиків.

Висновки зданого дослідження та перспективи. Виходячи з наведеного, слід зазначити, що поняття добровільного об'єднання територіальних громад слід розглядати як засноване на підвалинах конституційності та законності, добровільності, економічної ефрективності, державної підтримки, повсюдності місцевого самоврядування, прозорості та відкритості, відповідальності процесу укрупнення адміністративно-територіальних одиниць шляхом об'єднання суміжних територіальних громад у межах однієї області з урахуванням історичних, природних, етнічних, культурних та інших чинників, що впливають на соціально-економічний розвиток об'єднаної територіальної громади, ініціаторами якої виступають члени громади прямо або опосередковано через представників виборних органів місцевого самоврядування.

Варто зазначити, що попри певну нормативну неврегульованість на шляху добровільного об'єднання територіальних громад, можливо зробити попередні висновки про спроможність інституцій системи місцевого самоврядування України ефективно взаємодіяти 3 державними інституціями, здатність як протидіяти рішенням чи неправомірним діям державних органів влади у рамках чинного законодавства, попри певну консервативну неготовність останніх утримуватися від дій, що обмежують органи місцевого самоврядування як підвалини демократичного режиму та відповідати викликам демократичного суспільства на прикладі взаємодії з місцевими державними адміністраціями у процесі добровільного об’єднання територіальних громад.

\section{Список літератури:}

1. Моніторинг процесу децентралізації та редормування місцевого самоврядування Міністерства розвитку громад та територій України станом на 10 січня 2020 року. Інформаційний портал “Децентралізація". URL: https://decentralization.gov.ua/uploads/library/file/526/10.01.2020.pdf

2. Про добровільне об’єднання територіальних громад” : Закон України від 05.02.2015 р. № 157-VIII. Законодавство України : база даних / Верхов. Рада України. URL: https://zakon.rada.gov.ua/laws/show/157-19\#top

3. Конституція України : прийнята на п'ятій сесії Верховної Ради України 28.06.1996 р. Законодавство України : база даних / Верхов. Рада України. URL: https://zakon.rada.gov.ua/laws/show/254к/96-вp/ed20200101\#Text

4. Про місцеві державні адміністрації : Закон України № 586- XIV від 09.04.1999 p. URL: www.zakon1.rada.gov.ua

5. Концепція реформування місцевого самоврядування та територіальної організації влади в Україні : схвалено розпорядж. Каб. Міністрів України від 01.04.2014 р. o 333-р. Законодавство України : база даних / Верхов. Рада України. URL: https://zakon.rada.gov.ua/laws/show/333-2014-p\#Text

6. Про внесення змін до деяких законів України щодо добровільного приеднання територіальних громад : Закон України від 09.02.2017 № 1851-VIII. Законодавство України : база даних / Верхов. Рада України. URL: https://zakon.rada.gov.ua/laws/show/1851-19\#n9

7. Пояснювальна записка до проекту Закону України "Про внесення змін до деяких законодавчих актів України (щодо добровільного приеднання територіальних громад)”. Законотворчість : база даних / Верхов. Рада України. URL: http://w1.c1.rada.gov.ua/pls/zweb2/webproc4_2?pf3516=4772\&skl=9

8. Про місцеві державні адміністрації : Закон України від 9 квітня 1999 року № 586-XIV. Законодавство України : база даних / Верхов. Рада України. URL: https://zakon.rada.gov.ua/laws/show/586-14\#Text

9. Карта донорів децентралізації. Інформаційний портал “Децентралізація”. URL: https://donors.decentralization.gov.ua/projects

10. Галина Маркович. Особливості фрормування бюджетів об’єднаних територіальних громад, - роз'яснення експерта. Інформаційний портал “Децентралізація”. URL: https://decentralization.gov.ua/news/3958 


\section{References:}

1. Monitorynh protsesu detsentralizatsii ta reformuvannia mistsevoho samovriaduvannia Ministerstva rozvytku hromad ta terytorii Ukrainy stanom na 10 sichnia 2020 roku. Informatsiinyi portal "Detsentralizatsiia". Available at: https://decentralization.gov.ua/uploads/library/file/526/10.01.2020.pdf

2. Pro dobrovilne obiednannia terytorialnykh hromad": Zakon Ukrainy vid 05.02.2015 r. № 157-VIII. Zakonodavstvo Ukrainy: baza danykh / Verkhov. Rada Ukrainy. Available at: https://zakon.rada.gov.ua/laws/show/157-19\#top

3. Konstytutsiia Ukrainy: pryiniata na piatii sesii Verkhovnoi Rady Ukrainy 28.06.1996 r. Zakonodavstvo Ukrainy: baza danykh / Verkhov. Rada Ukrainy. Available at: https://zakon.rada.gov.ua/laws/show/254k/96-vr/ ed20200101\#Text

4. Pro mistsevi derzhavni administratsii: Zakon Ukrainy № 586-XIV vid 09.04.1999 r. Available at: www.zakon1.rada.gov.ua

5. Kontseptsiia reformuvannia mistsevoho samovriaduvannia ta terytorialnoi orhanizatsii vlady v Ukraini: skhvaleno rozporiadzh. Kab. Ministriv Ukrainy vid 01.04.2014 r. No 333-r. Zakonodavstvo Ukrainy: baza danykh / Verkhov. Rada Ukrainy. Available at: https://zakon.rada.gov.ua/laws/show/333-2014-r\#Text

6. Pro vnesennia zmin do deiakykh zakoniv Ukrainy shchodo dobrovilnoho pryiednannia terytorialnykh hromad: Zakon Ukrainy vid 09.02.2017 № 1851-VIII. Zakonodavstvo Ukrainy: baza danykh / Verkhov. Rada Ukrainy. Available at: https://zakon.rada.gov.ua/laws/show/1851-19\#n9

7. Poiasniuvalna zapyska do proektu Zakonu Ukrainy "Pro vnesennia zmin do deiakykh zakonodavchykh aktiv Ukrainy (shchodo dobrovilnoho pryiednannia terytorialnykh hromad)". Zakonotvorchist: baza danykh / Verkhov. Rada Ukrainy. Available at: http://w1.c1.rada.gov.ua/pls/zweb2/webproc4_2?pf3516=4772\&skl=9

8. Pro mistsevi derzhavni administratsii: Zakon Ukrainy vid 9 kvitnia 1999 roku № 586-XIV. Zakonodavstvo Ukrainy: baza danykh / Verkhov. Rada Ukrainy. Available at: https://zakon.rada.gov.ua/laws/show/586-14\#Text

9. Karta donoriv detsentralizatsii. Informatsiinyi portal "Detsentralizatsiia". Available at: https://donors.decentralization.gov.ua/projects

10. Halyna Markovych. Osoblyvosti formuvannia biudzhetiv obiednanykh terytorialnykh hromad, - roziasnennia eksperta. Informatsiinyi portal "Detsentralizatsiia". Available at: https://decentralization.gov.ua/news/3958 